\title{
СИНТЕЗ И АНТИОКСИДАНТНАЯ АКТИВНОСТЬ ПРОСТРАНСТВЕННО-ЗАТРУДНЕННЫХ ПИРОКАТЕХИНОВ С МЕТИЛЕН-ТИОЭФИРНЫМ ЛИНКЕРОМ
}

\author{
И.В. Смолянинов ${ }^{1}$, М.В. Арсеньев², Д.А. Бурмистрова', \\ М.А. Хахалева ${ }^{3}$, Н.Т. Берберова' \\ ${ }^{1}$ ФГБОУ ВО «Астраханский государственный технический университет, \\ 414056, Россия, г. Астрахань, ул. Татищева 16. \\ 2ФГБУН Институт металлорганической химии им. Г.А. Разуваева РАН, \\ 603137, Россия, г. Нижний Новгород, ул. Тропинина, 49. \\ ${ }^{3}$ ФГБУ Федеральный исследовательский центр Южный научный центр РАН, \\ 344006, Россия, г. Ростов-на-Дону, пр. Чехова, 41.
}

DOI: 10.19163/MedChemRussia2021-2021-284

E-mail: ivsmolyaninov@gmail.com

В работе получена серия новых 3-метилтиозамещенных пирокатехинов 1-11 на основе взаимодействия 3,5-ди-трет-бутил-6-метоксиметилпирокатехина с тиолами различного строения. Выход целевых соединений варьировался от 47 до $83 \%$.

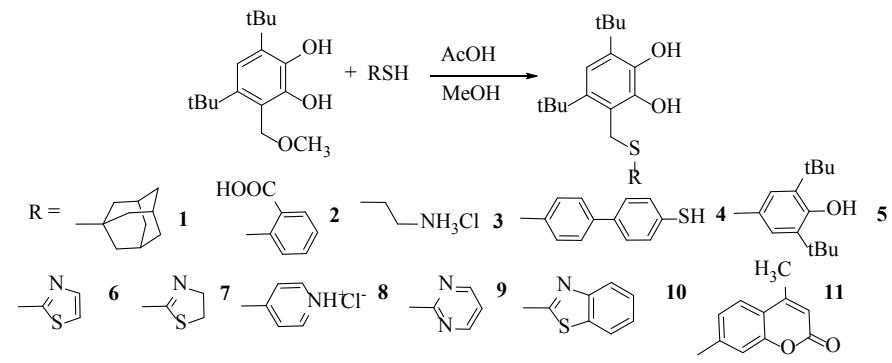

Исследованы антиоксидантные свойства тиоэфиров в различных модельных реакциях. Взаимодействие пирокатехинов со стабильным ДФПГ радикалом протекает в течение 5-60 мин, показатель $\mathrm{EC}_{50}$ изменяется в диапазоне от 7.5 до 23.2 нмоль. Наибольшая антирадикальная активность характерна для соединений 2,4 и 6. В реакции окислительного повреждения молекулы ДНК, промотированной ААРН, большинство веществ обладают умеренной антиоксидантной активностью. Соединение 4 с тиольной группой оказывает промотирующий эффект в данном тесте. В процессе пероксидного окисления липидов (ПОЛ) in vitro в присутствии тиэфиров 3, 6-11 наблюдается выраженное антиоксидантное действие, эффективность которого возрастает во времени. Пирокатехины 1 и 4 интенсифицируют реакцию ПОЛ.

Работа выполнена при финансовой поддержке Российского научного фонда (проект № 20-13-00084). 